\title{
Pre-natale sterfte en ritueel: \\ Die behoefte aan ' $n$ betekenisvolle \\ ritueel in die hantering van 'n miskraam \\ of aborsie
}

\author{
Johan Nel (Bloemfontein) \\ Departement Praktiese Teologie \\ Universiteit van die Vrystaat
}

\begin{abstract}
Pre-natal death: The need for employing a meaningful ritual towards coping with a miscarriage or an abortion

Both religion and ritual amongst others are ways by which people can express feelings in their relationships with others, the world and the Almighty God. Religion and ritual are often used to come to a better understanding and to cope with loss. In the postmodern era, a holistic approach towards therapies has been developed. Pastoral therapy is a part of this process. This article examines the use of rituals as a possible therapeutical method for coming to terms with loss after the occurence of pre-natal death. The article argues that a meaningful ritual can be used to assist people who have experienced miscarriage or abortion.
\end{abstract}

\section{INLEIDING}

\author{
Happy birthday \\ Please accept my apologies, wonder what would have been \\ would you have been a little angel? Or an angel of sin? \\ tom-boey running around, hanging with all the guys? \\ or a little tough boy with beautiful brown eyes? \\ paid for the murder before they had determined the sex \\ choosing our life over your life meant your death \\ and you never got a chance to even open your eyes \\ sometimes I wonder as a fetus if you fought for your life? \\ Would you have been a little genius, in love with math? \\ Would you have played in your school clothes and made me mad? \\ I wonder about your skintone and shape of your nose
}


and the way you would have laughed and talked fast or slow

I think about it every year, so I picked up a pen

Happy birthday, I love you whoever you would have been

\author{
from the heaven to the womb \\ to the heavens again \\ from the ending to the ending \\ never got to begin \\ maybe one day we can meet face to face \\ happy birthday
}

Hierdie woorde kom uit 'n populêre liedjie getiteld "Flipside", gesing deur 'n popgroep met 'n eendersklinkende naam: Flipsyde. Die kunstenaar sing oor 'n kind wat nooit die lewenslig aanskou het nie. Indien die kind oor wie gesing word, geleef het, sou dit sy of haar verjaarsdag gewees het. Die fetus is egter voor geboorte geaborteer. Die ouers verwoord en verklank nou hulle wroeging en intense leed, hartseer en selfverwyt vanweë hierdie verlies. Onmiddellik ontstaan vrae, wat tipies is in 'n situasie van hopeloosheid en uitsigloosheid; oor tyd wat uitgeloop het en nooit weer teruggekry kan word nie, en verkeerde keuses wat hulle gemaak het. Is hierdie liedjie dalk 'n voorbeeld van een van die wyses waarop daar deur middel van 'n ritueel of rite ventilering kan plaasvind wat skynbaar nodig is in die hantering van 'n verlies van hierdie aard? Die herhalende refrein is: "I think about it every year, so I picked up a pen ..." (my beklemtoning).

Die optel van 'n pen, en die skryf van 'n lied is hier betekenisvol. Dit verwys na 'n ritueel wat moontlik deur getraumatiseerdes as verwerkingstrategie gebruik kan word. En meer spesifiek, in die geval van die verlies van 'n kind wat pre-nataal gesterf het, 'n ritueel wat betekenisvol kan wees. Hierdie artikel ondersoek die verlies wat ontstaan wanneer 'n swangerskap termineer. Verder dui die navorsing van Defrain (1991), Henley (1991) en Lachelin (1985) aan dat die nasorg vir die betrokkenes dikwels ontbreek. 'n Betekenisvolle ritueel sou hierdie leemte kon vul deur die verlies terapeuties te hanteer, deur te werk en af te handel.

\title{
2. POSTMODERNITEIT
}

Met die aanbreek van die postmoderne era het grense onherroeplik verskuif, en baie dinge is gerelativeer. Mense word elke dag gekonfronteer met ' $n$ dualiteit: tegnologiese vooruitgang, met byvoorbeeld rekenaartegnologie, die (mediese) wetenskap, ensomeer. Daar is egter grootskaalse verval andersyds. Voorbeelde van geweld, aggressie, die MIV/Vigs-pandemie en die 
hoë misdaadsyfer, en nog meer voorbeelde is talryk. In hierdie konteks word daar allerweë verwys na 'n sogenaamde "paradigmaskuif" wat plaasgevind het van moderniteit na postmoderniteit.

Müller (1996:54) maak daarvan melding dat 'n verstaan van die konsepte van "moderniteit" en "postmoderiteit" nie eenvoudig en klinkklaar is nie. Cilliers (2002:1) meld verder dat sommige postmoderniste selfs sover sou gaan as om te beweer dat 'n defenisie van postmoderniteit 'n contradictio in terminis is: wie 'n greep op die verskynsel wil kry, verstaan dit nie. Van Rensburg (2000:1) verwys na die paradigma van waaruit geopereer word, as die raamwerk van denke, 'n "... frame of mind." Hy brei verder daarop uit deur te sê: "A paradigm is a frame of mind, a frame of reference, and a point of departure from which one thinks ... A paradigm does to one's view of life almost what a frame does to a painting ... The frame keeps the painting together and defines the character." Wanneer daar gepraat word van 'n paradigmaskuif van moderniteit na postmoderniteit, behels dit 'n bepaalde verstaan van die werklikheid in 'n sekere konteks. Postmoderniteit as paradigma maak dit moontlik om in 'n sekere sin nou terug te staan, en van 'n afstand na die "skildery" binne die raam van postmoderniteit te kyk.

In die vorige era, die sogenaamde modernisme, is kognitiewe rasionele denke oorbeklemtoon (Van Aarde 1990:293). Modernisme sou verstaan kon word as 'n lewenshouding waarin daar vasgehou word aan 'n objektiewe werklikheid wat geken en nagevors kan word (Greyling \& Müller 2002:30). Vir McLaren (2002:162-166) is daar vyf waardes ter sprake wanneer dit weer by postmodernisme kom:

- $\quad$ Skepties oor sekerhede

- Sensitief vir die konteks

- Geneigdheid tot humor

- Subjektiewe ervaring

- Samehorigheid.

Ter illustrasie word verwys na Maritz \& Dreyer (2001:1266) wat in 'n artikel oor musiek as hulpmiddel in pastorale terapie, na die invloed van die oorskatting van die kognitiewe kyk wat kenmerkend was aan die modernisme. Dit beïnvloed die mens se rede en kognitiewe vermoë en verhouding met sigself, ander en die natuur op so 'n wyse dat die mensbeeld verskraal word. Die gevolg hiervan, konkludeer Maritz, is dat die gevoelsmatige, die metafisiese en estetiese op die agtergrond geskuif word ter wille van die rasionele magsbeheptheid van die subjek. Die gevolg is 'n vervreemding tussen mense en hulle essensiële behoefte aan die uitlewing in byvoorbeeld 


\section{Pre-natale sterfte en ritueel}

verskillende kunsvorme. Vir die doel van hierdie artikel, sou die gebruikmaking van 'n ritueel as vorm van uitdrukking, hierby gevoeg kon word. Krities sou gevra kon word of die tradisionele Gereformeerde spiritualiteit nie dalk gebuk gaan onder 'n gebrek aan die moontlikheid van uitdrukking van ervaring en gevoelens nie, en of die strewe na soberheid en nugterheid nie dalk 'n emosionele armoede tot gevolg het nie. 'n Neweproduk hiervan sou moontlik kon manifesteer in 'n ontkenning van die emosionele behoeftes van ouers wat byvoorbeeld 'n kind as gevolg van 'n miskraam verloor. Op die vraag of daar kategorieë van verlies bestaan, toon die navorsing van $\mathrm{Nel}$ (2000) dat daar, in elk geval in die geval van 'n miskraam, die emosies na die verlies van 'n swangerskap, en die afgee van 'n kind aan die dood, baie sterk ooreenkomste toon.

In die postmoderne idioom het die bakens van wat waarheid is, verskuif. Om spekulatief en verkennend te waag, selfs om vaag te wees oor 'n bepaalde onderwerp word erken as 'n werklikheid. Ervaring het dieselfde gesag as afdoende bewyse. Postmoderne hermeneutiek stel hom ten doel om te verstaan eerder as om te verklaar. Van Aarde (1995:20) poneer:

"Postmoderniteit wil die pragmatiese en affektiewe dimensies van menswees náás die kognitiewe beklemtoon." Aan die individu word die moontlikheid gebied om op verskillende vlakke te dink. Waar daar in 'n vroeëre paradigmatiese konteks namens mense gedink en besluit is oor morele en etiese kwessies, en dit selfs deur wetgewing beheer is, word die huidige tydvak gekenmerk deur outonomiteit. Die vraag ontstaan nou of die individu oor die nodige vaardighede beskik om die gevolge van die vryheid van keuse te kan hanteer. Die moontlikheid om 'n fetus te aborteer, kan in hierdie dae op aanvraag geskied. Maar is die ondersteuning en begeleiding van die betrokkenes voldoende? En wat van ouers wat 'n kind verloor as gevolg van 'n miskraam? Hier is die leemte: die Westerse samelewing staan skynbaar koud en klinies hierteenoor, en selfs in die kerk vind hierdie mense nie 'n holte vir die voet nie nadat hulle hierdie verlies beleef het nie. Weliswaar kom die versuim waarskynlik nie uit onverskilligheid aan die kerk se kant nie, maar bloot weens 'n gebrek aan insig in die situasie. Sou die ondersteuningstelsel en by name die geestelike leiers, pastorale terapeute en gemeentelike geestelike werkers nie onder andere by wyse van 'n ritueel die leemte kon vul nie? Op hierdie vrae word in hierdie artikel gereageer.

\section{DIE LEEMTE}

Die insidensie van swangerskappe wat voortydig beeïndig word, is baie hoog. Beide Hunt (1984:263) en Tucker (1989:11) se navorsing toon dat ongeveer $25 \%$ van alle swangerskappe in 'n miskraam eindig. Die teodisee-vraag kom onmiddelik aan die orde. Hierdie sinvraag behels enersyds die vraag na die 
sin van die lewe, en dan die sin van lyding. Sinsbemiddeling moet bewerkstellig word. Dit is belangrik om op te merk dat aborsie en miskraam nie sinonieme is nie. By ' $n$ aborsie word die swangerskap getermineer en in die geval van 'n miskraam verloop die proses van terminasie spontaan. Die fokus van hierdie ondersoek is egter die emosionele impak wat die verlies van die fetus kan hê, wat van toepassing kan wees by beide die gevalle.

Die navorsing van $\mathrm{Nel}$ (2000) het uitgewys dat daar 'n definitiewe leemte bestaan in die versorging van persone wat ' $n$ miskraam beleef het en dat gesinne juis in hierdie traumatiese ervaring die behoefte het aan pastorale begeleiding. Indien die effek van 'n miskraam beter deur die pastor begryp word, kan dit bydra tot meer sinvolle en doelgerigte pastorale hulpverlening. Die belewing van 'n miskraam word dikwels met ongemak en lompheid deur die pastor hanteer. Dikwels gaan die gebeure ongemerk verby. Die potensiaal bestaan egter dat die onverwerkte emosie in patologie kan oorgaan. Lachelin (1985:63) dui aan dat die verlies van 'n fetus, hetsy in 'n vroeë of latere stadium van swangerskap, ' $n$ impak het op die vrou wat dit fisies beleef, asook op almal met wie sy interaksie het. Vir 'n gelowige sal die verlies van 'n ongebore baba nooit ' $n$ toevalligheid wees nie. Tog is daar weinig vanuit 'n pastorale perspektief beskikbaar om die pastor te help in sy begeleiding van sulke mense.

Dit is ook belangrik om daarvan kennis te neem dat daar wel 'n klein persentasie van mense is wat 'n miskraam beleef, maar dit nie as traumaties ervaar nie. Brown (1993) meld dat, hoewel die verlies van 'n swangerskap vir die meerderheid mense verpletterend is, daar tog ook diegene is wat verlig is, veral wanneer die swangerskap op 'n ongeleë tydstip gekom het. Hier word veral na ongewensde buite-egtelike en tienerswangerskappe verwys. Die voorkoms van probleme in die latere lewe, kan egter ook nie ontken word nie omdat dit deur navorsing ondersteun word. Hier is Hunt (1984:270) se bevinding belangrik. Hy maak daarvan melding dat indien die moeder aanvanklik ontevrede was met die swangerskap, en selfs 'n aborsie oorweeg het, sy dikwels ambivalente of selfs diepe skuldgevoelens beleef het na die miskraam. Hierdie onverwerkte gevoelens word saam die toekoms ingedra en manifesteer dikwels in problematiek in latere verhoudings.

Die begeleiding van hierdie mense, moet in groot verantwoordelikheid hanteer word. Anders as in die geval waar daar 'n oorskot is wat begrawe word, is die uitdaging juis om op 'n sinvolle wyse tot sluiting te kom. 'n Betekenisvolle ritueel sou hier van waarde kon wees.

\section{RITUELE}

Elke kultuur skep vir homself meganismes wat binne sy eie konteks op sosiaal aanvaarbare wyse geleentheid bied om uiting te gee aan 'n emosie. So bied 
' $n$ begrafnis in sekere kulture byvoorbeeld aan bedroefdes die geleentheid om deur middel van 'n "openbare forum" op 'n sosiaal aanvaarbare wyse uiting aan die emotiewe te gee. Wyrostock (1995:397) formuleer dit soos volg:

\begin{abstract}
Rituals have always been a part of the very existence of every culture. A ritual can be described as an action which is performed by a specific group of people, through which they express the very essence of their being. Whether it is sadness or joy, the symbolic acting out through the ritual conveys a specific form of communication which is felt in the heart.
\end{abstract}

Ook Menken-Bekius (2000) handel uitvoerig oor die prakties-teologiese belang van rituele. Dit is derhalwe aanvaarbaar (en word selfs verwag!) dat families oor hulle dooies sal rou. Dikwels neem die rouproses ' $n$ aanvang met die openbare begrafnisseremonie. Die begrafnis bied derhalwe ' $n$ forum vir die uitspeel van emosies. Dit is juis hier waar die knoop lê vir ouers wat 'n kind verloor as gevolg van 'n miskraam. Die navorsing toon aan dat die verlies wat ouers beleef nadat ' $n$ kind op hierdie wyse verloor word, in 'n groot mate ooreenstem met die verlies van 'n baba of kind na geboorte. Die leemte lê daarin dat die rouproses in hierdie geval selde of nooit afgehandel word, en dikwels oorgaan in patologie.

\title{
4.1 Die terapeutiese waarde van 'n ritueel
}

\subsubsection{Pastorale terapie}

Vir Louw (1993) staan drie aspekte sentraal in die kommunikasiegebeure tussen God en mens in die pastorale gesprek. Dit is die aspek van beïnvloeding, verandering en herstel of vernuwing. Hierdeur word mense in die lig van die paraklesemetafoor getroos tot lewe, te midde van ontwrigtende lewensomstandighede en nood. Louw maak 'n belangrike stelling in hierdie verband: "Nie waar lewe is, is daar hoop nie, maar waar hoop is, is daar lewe" (Louw 1993:375). Die mens kan in sy gebrokenheid ontdek dat hy reeds met God versoen is, en dan te leef vanuit hierdie heilservaring. In pastorale terapie word die eiesoortige kernwaarhede van die pastoraat as vertrekpunt gesien.

Dit loop uiteindelik uit op 'n nuwe werklikheid, wanneer die heil prakties gelééf word.

In pastorale terapie sou daar myns insiens gepraat kon word van 'n snydingsmoment. Pastorale terapie aan die een kant, en die eksternaliseringsbeginsel (White 1990) wat die narratief onder andere bedien 
andersyds, word die nuwe moontlikheid in die lewe van 'n gelowige mens 'n nuwe werklikheid.

\subsubsection{Die krag van simboliek}

Van altyd af was simboliek deel van die bestaan van die mens. Simbolisering het verskillende funksies. "Symbolization is a universal human process. In a symbol there is both concealment and revelation" (Firth 1993:15). Mens leef egter nie alleen deur simbole nie, maar dit orden en interpreteer die mens se realiteite, breek dit af en dien herkonstruerend tot nuwe realiteite.

Dit is belangrik om te let op die kommunikatiewe waarde van simbole. Firth stel: "Ritual is a mode of communication, of 'saying something' in a formal way, not to be said in an ordinary language or informal behaviour" (Firth 1993:176). Simboliek het die vermoë om op 'n dieper vlak tot mense te spreek. ' $n$ Ritueel sou verstaan word as die verpraktisering van 'n simbool.

Verder mag gespekuleer word dat die simboliese waarde van 'n ritueel 'n leemte ("shortfall") in die gekommunikeerde werklikheid aandui. "This idea of 'not to be said' in a formal way means that a special character of ritual is its reserve, its apartness, its 'sacred' quality" (Firth 1993:176). Vir Vos (2005:176) kom spirituele uitlewing ook deur rituele na vore.

\subsubsection{Die waarde van rituele}

Nel (2000:95) meen dat juis in die rituele wat 'n kultuur vir homself daarstel, die rouproses na ' $n$ verlies aan die gang kom. Aanvaarbare rituele, soos byvoorbeeld ' $n$ begrafnis, bied as 't ware ' $n$ forum waarop die bedroefdes hulle emosies kan uitleef. Juis hier lê die knoop met ouers wat 'n baba as gevolg van 'n miskraam verloor het. Imber-Black, Roberts en Whiting (1988:8) sluit aan:

Rituals are coevolved symbolic acts that include not only the ceremonial aspects of the actual presentation of the ritual, but the process of preparing for it as well. It may or may not include words, but have both open and closed parts which are "held" together by a guiding metaphor. Repetition can be a part of rituals either through the content, the form, or the occasion. There should be enough space in the therapeutic rituals for the incorporation of multiple meanings by various family members and clinicians, as well as a variety of levels of participation. 
Ook Kübler-Ross (1974:101) het dekades gelede al geoordeel dat naasbestaandes deur middel van (begrafnis)rituele uitdrukking moet gee aan hulle persoonlike emosionele behoeftes. Dit behoort op só 'n wyse beplan word dat die wense van die naasbestaandes bevredig kan word. Die vraag ontstaan onwillekeurig of die streng, voorskriftelike en resepmatige begrafnisen roudienste wat deel uitmaak van tradisionele spiritualiteit nie dalk die emosionele behoeftes van treurendes ontken en uiteindelik inhibeer nie.

Vos (2005:173) verwys na die sogenaamde "postmoderne heiliges". Hy haal ' $n$ voorbeeld aan uit 'n artikel van Marcel Barnard (2001) wat aantoon hoe prinses Diana die status van 'n postmoderne heilige verkry het. Die baie bossies vars blomme as teken van publieke rou dui op 'n noodsaaklike rituele uitbarsting van 'n volk in rou. Dit illustreer egter veel meer: dit wys op die totstandkoming van 'n nuwe sisteem, met die vermenging van 'n tradisionele Christelike tradisie, popmusiek verwysend na die lied "Candle in the wind" wat in die kerk deur Elton John gesing is, en familiebetrokkenheid wat vergestalt in die toespraak deur die oorledene se broer. Hierdie voorbeeld vertel 'n verhaal van postmoderniteit, 'n alternatiewe manier van rou. Vos (2005:175) se opmerking oor ritusse is waardevol wanneer hy die volgende opmerking maak: "Ritusse is sekere (gewoonte-)handelinge waaraan mens vashou." Hoewel hierdie rituele in die Gereformeerde tradisie waarskynlik onder geweldige kritiek sou deurloop, moet die sinvolheid en betekenisfunksie daarvan uitgedaag word. Flipsyde se "I think about it every year, so I picked up a pen ..." sou goedskiks as nog 'n voorbeeld hierby gevoeg kon word. In terapeutiese taal is betekenisvolle ritualisering die ideaal.

\subsubsection{Die teologiese betekenis van die begrafnisritueel}

Dwarsdeur die Ou Testament word verwys na sorg na die afsterwe van 'n persoon. 'n Fatsoenlike ritueel was vanselfsprekend (De Vaux 1978:56). Sodra die nuus van die sterfte ontvang is, het die proses hom begin afspeel: die familielede het hulle klere geskeur as teken van rou; ' $n$ kledingstuk van growwe materiaal is aangetrek, en die roubeklaers het hulle skoene uitgetrek en hoofbedekkings is verwyder; grond of as is op die hoof gestrooi, en die persoon het fisies in die as gaan sit; hare en baarde is afgeskeer, en die roubeklaers het hulself selfs gemutileer. Laastens is daar ook nie enige voedsel gedurende hierdie tyd voorberei nie. Tydens die begrafnis is die naam van die oorledene kort-kort uitgeroep, asook die sogenaamde "wee" uitroepe. Hierdie openbare ritueel bied ' $n$ vorm van ventilering van die smart en verlies.

Die vroeë Christene het hulle rou anders hanteer as die heidene. Rutherford (1980:15) stel: "In Christian funeral orations one is struck by the way in which life and resurrection renders mourning unchristian, whereas it 
respects the genuine grief of the bereaved". Om na die dooies om te sien was nog altyd ook ' $n$ integrale deel van die Christendom. Hierdie praktyke en rituele rondom die hantering van die dooies totdat hulle te ruste gelê word, het ontwikkel uit kerklike tradisies. Die kerk hou vandag steeds tradisies en rituele in stand. Juis hierin is die uitdaging vir die kerk vandag: dat daar na 'n miskraam ook 'n aanvaarbare ritueel sal plaasvind sodat die ouers sluiting kan kry.

\subsubsection{Miskrame en aborsies in die Bybel}

Verwysings na miskrame in die Bybel is baie skaars. Dit is derhalwe onmoontlik om sondermeer uit die Bybel enige afleiding te maak van die hantering van 'n verlies van hierdie aard. Wanneer daar wel na miskrame of "misgeboortes" verwys word, is dit byna terloops. Eksodus 21:22 maak 'n juridiese uitspraak: "Wanneer mans met mekaar baklei en hulle ' $n$ swanger vrou omstamp, sodat sy 'n miskraam het maar nie blywend beseer is nie, moet hy wat haar gestamp het, onderhewig aan die goedkeuring van die regbank, die boete betaal wat die eggenoot van die vrou hom oplê." Die kultuur van die tyd het dit as skande beskou indien 'n man nie 'n nageslag gehad het nie. Die seën van die Here het tot uitdrukking gekom in die talrykheid van die nageslag. Eksodus reël dus hier slegs finansiële kompensasie vir die verlies aan 'n lewe. Geen melding word gemaak van die emotiewe nie.

Waar in Job 3:16 'n verbitterde Job aan die woord kom, vervloek hy sy geboortedag en wens dat hy eerder 'n misgeboorte was. Hierdie opmerking lig die sluier effens oor die wyse waarop daar met die oorskot van 'n ongebore fetus te werk gegaan is. Dit wil voorkom asof dit, in Job se woorde "... sonder meer begrawe ..." is. Weer eens word geen emosie hier hanteer nie.

\subsubsection{Die verbond}

In die gesprek oor verwerkingstrategieë na die verlies van 'n pre-natale lewe, en die impak wat dit op die ouers het, moet noodwendig ook kortliks gevra word na die ewige bestemming van die ongeborene. Zuck (1996:21) vra (saam met baie ouers) 'n aantal belangrike vrae met betrekking tot die sondigheid al dan nie van 'n kind: "Are infants born with a sin nature? What is the so-called 'age of accountability' ... Are children of Christian parents in a covenant relationship to God?" Van Niftrik (1944:238) poneer dat die sonde so diep in ons ingebore is, dat selfs ons edelste gevoelens en dade op die keper beskou eintlik ook ' $n$ uiting is van ons eie diepgewortelde selfsug. Die sonde moet geglo word, net soos ons geregtigheid in Christus geglo moet word. Ons weet egter dat ons voor God moet neerbuig en die vergifnis lééf, want God 


\section{Pre-natale sterfte en ritueel}

het in Christus neergebuig en langs die sondaar kom staan, en God so solidêr met die mens gemaak. As ons dan, soos in die belydenisskrifte uiteengesit, in sonde ontvang en gebore is, en alleen op grond van genade verlos word, dan is ons reeds vóór geboorte verlos. Die uitverkiesing staan ook direk in verband met die genade van God. Ons verdien dit immers nie. In die lig hiervan, word die ongeborene ook by hierdie genade ingesluit. Dit is vir ouers wat 'n baba pre-nataal verloor, nodig om hierdie heilsfeit te glo.

Hierby sluit Weber (1983:412) aan: "The reality which quickens both the Christian message and therefore theology is that God as the 'Trancendent', that is, as He Himself, is in free self-detemination the 'Immanent', the One who turns to the lost creature ... In Him, God's freedom in his grace and God's grace in his freedom are decided."

\section{NUWE MOONTLIKHEDE: SIMBOLE EN RITUELE}

'n Simbool staan vir Vos (2005:176) teenoor 'n wetenskaplike term. 'n Simbool het sogenaamde "oop" moontlikhede en wat verskillende betekenisse kan insluit. Simbole word dan deur rituele handeling gedra. "Rites weef 'n patroon waarvolgens die simbole se skoonheid, waarde en betekenis na vore kom" (Vos 2005:179).

Die verlies van pre-natale lewe moet eerstens as 'n verlies erken word. Voor dit nie gebeur nie, kan rouwerk nie afgehandel word nie. Smith (2003:154) praat van kroniese of "no end" -rou. Die verlies van 'n fetus is ook die verlies van 'n droom.

Deur middel van 'n simbool kan die "pen" waavan Flipsyde sing, 'n rouproses aan die gang sit. Die skryf van 'n brief, gedig, of lied is maar een van verskeie moontlikhede.

\section{GEVOLGTREKKINGS EN AANBEVELINGS}

Nood vra na betrokkenheid. Navorsing toon duidelik 'n leemte in die betrokkenheid van medegelowiges, predikante en geestelike leiers by ouers wat 'n miskraam beleef. Die onbetrokkenheid is nie doelbewus nie, maar eerder die gevolg van onkunde oor die intensiteit van die pre-natale verlies, en die impak daarvan op die persone wat dit beleef.

Veral van die kant van die pastorale terapie kan met kreatiwiteit gewerk word aan die daarstel van sinvolle rituele om saam met die beproefdes deur te werk. Die gesin as sisteem word geraak, en moet dus sodanig hanteer word. Geestelike bemoeienis is die taak van die kerk. Predikante kan in toerustingskursusse bewus gemaak van verliessituasies wat buite die "gewone" gebeur, met toepaslike ondersteuning as moontlikheid. Verder is 
deeglike kennis van die teorie rondom rousmart onontbeerlik vir enige persoon wat betekenisvol betrokke wil raak by ander in nood. Veral is 'n deeglike teoretiese onderbou ten opsigte van kroniese-, verlenge en patologiese rou. Inligting rondom die teologiese perspektiewe op die status van die fetus moet deeglik verdiskonteer word. Vervolgens word ritualisering gekontekstualiseer en is dit waardevol. Uiteindelik word die hoop in Christus verkondig.

\section{Literatuurverwysings}

Cilliers, J 2002. Prediking as spel: 'n Homileties-etiese perspektief op postmodernisme. Praktiese Teologie in S A 17(1), 1-27

Defrain, J 1991. Learning about grief from normal families: Stillbirth and miscarriage. Journal of marital and family therapy 17(3), 215-232

De Vaux, R 1978. Ancient Israel: Its life and institutions. London: Darton, Longman \& Todd.

Firth, R 1993. Symbols public and private. New York: Cornell University Press.

Greyling, H \& Müller, J 2002. Sekerheid en onsekerheid binne die pastoraalterapeutiese situasie. Praktiese Teologie in S A 17(1), 28-42.

Henley, A 1991. Miscarriage, stillbirth and neonatal death: Guidelines for professionals. London: SANDS.

Hunt, S 1984. Pastoral care and miscarriage: A ministry long neglected. Pastoral Psychology 32(4), 265-276.

Imber-Black, Roberts, J \& Whiting, R A 1988. Rituals in families and family therapy. New York: W W Norton.

Kübler-Ross, E 1974. Questions and answers on death and dying. New York: Macmillan.

Lachelin, G C L 1985. Miscarriage: The facts. Clarendon: Oxford University Press.

Louw, D J 1993. Pastoraat as ontmoeting. Ontwerp vir 'n basisteorie, antropologie, metode en terapie. Pretoria: RGN-Uitgewery.

Maritz, J F \& Dreyer T F J 2001. Musiek as hulpmiddel in pastorale terapie. HTS 57(3\&4), 1265-1287.

Menken-Bekius, C 2000. Rituelen in het individuele pastoraat: Een praktisch theologisch onderzoek. Kampen: Kok

McLaren, B D 2000. The Church on the other side: Doing ministry in the postmodern matrix. Michigan, MI: Zondervan

Müller, J 1996. Om tot verhaal te kom: Pastorale gesinsterapie. Pretoria: Raad vir Geesteswetenskaplike Navorsing.

$\mathrm{Nel}, \mathrm{J} 2000$. Die pastorale versorging van die gesin wat 'n miskraam beleef het - 'n prakties teologiese perspektief. PhD-proefskrif, Departement Praktiese Teologie, Universiteit van Pretoria.

Rutherford, R 1980. The death of a Christian: The rite of funerals. New York: Pueblo.

Smith, W J 2002. 'n Prakties -teologiese perspektief op hoop as pastorale bemagtiging en verryking in die rouproses. PhD-proefskrif, Departement Praktiese Teologie, Universiteit van Pretoria. 
Tucker, K B 1989. A pastoral response to silent tragedy. The Christin Ministry 20, 1113

Van Aarde, A G 1990. Holisme as 'n postmodernistiese filosofie in teologiese lig. HTS 46, 293-311.

Van Aarde, A G 1995. Kerk en teologie op pad na die derde millennium: 'n Paradigmatiese verskuiwing van middelmatige aard. HTS 51, 3-12.

Van Niftrik, G C 1944. Kleine Dogmatiek. Nijkerk: G F Callenbach.

Van Rensburg, J J 2000. The paradigm shift: An introduction to postmodern thought and its implications fot theology. Pretoria: Van Schaik.

Vos, C J A 2005. Die krag van simbole en rites in die liturgie. Acta Theologica 25, 172-187.

Weber, O 1981. Foundations of dogmatics. Grand Rapids, Ml: Eerdmans.

White, M \& Epston, D 1990. Narrative means to therapeutic ends. New York: W W Norton.

Zuck, R B 1996. Precious in His sight: Childhood in the Bible. Grand Rapids, MI: Baker Books. 